\title{
Titae
}

35 (2019) 167-185

\section{Janusz Kręcidło}

Uniwersytet Kardynała Stefana Wyszyńskiego, Warszawa

j.krecidlo@wp.pl, ORCID:0000-0002-0913-5513

\section{JEZUS A CZAS W PERSPEKTYWIE \\ ANTROPOLOGII KULTUROWEJ}

Jesus and Time

from the Perspective of Cultural Anthropology

Artykuł ma szeroką formułę. Najpierw przedstawiono w nim syntetycznie najważniejsze fizyczne, filozoficzne, socjologiczne i antropologiczne ujęcia czasu. Na tym zaś tle ukazano poglądy dotyczące orientacji czasowej w kulturze starożytJezus, czas, Nowy Testament, antropologia nego świata śródziemnomorskiego. Zagadnienia kultury te posłużyły jako tło do wyeksponowania tematyki doświadczania czasu przez Jezusa i Jego uczniów ze wskazaniem zasadniczego przeorientowania w związku ze zbawczym wydarzeniem męki, śmierci i zmartwychwstania Chrystusa. Dla ludzi Nowego Testamentu przeszłość, teraźniejszość i przyszłość ogniskują się w wydarzeniu Chrystusa i w Nim nabierają sensu. W jego perspektywie aktualizują się wszystkie przeszłe wydarzenia. W Jezusie również rozpoczyna się eschatologiczna przyszłość, która w każdym kolejnym pokoleniu chrześcijan powinna być przeżywana jako „teraz” zbawienia. 
The article encompasses a wide field of reference. First, it presents synthetically the most important physical, philosophical, sociological and anthropological concepts of time. Against this background, the notions of temporal orientation within the cultures of the ancient Mediterranean world are shown. These perspectives serve as background for examining the subject of how time was experienced by Jesus and His disciples, noting the fundamental reorientation inherent in the salvific event of the Passion, Death and Resurrection of Christ. For the people of the New Testament, the past, present and future all converge and focus in the Christevent. In Him, all these dimensions make coherent sense. All past events are reoriented to this perspective and likewise in Jesus the eschatological future begins, which every subsequent generation of Christians should live as the "now" of salvation.

Czas jest bardzo efemeryczną rzeczywistością. Stwierdzenie to dotyczy zarówno trudności z uchwyceniem upływającego czasu, jak i ze znalezieniem słów, zdań i koncepcji zdolnych opisać ten fenomen. We współczesnym dyskursie na temat czasu dominują trzy perspektywy: czas jako zjawisko fizyczne, filozoficzne koncepcje czasu oraz uwarunkowania kulturowe doświadczenia czasu. W niniejszym artykule najpierw popatrzymy na te kwestie, by następnie przejść do zagadnień, które są głównym przedmiotem naszego zainteresowania w tym artykule: jak postrzegano zjawisko czasu w kulturze, w której żył Jezusa i w której powstały księgi Nowego Testamentu? oraz jaki ma to wplyw na teologiczną interpretację biblijnych tekstów? Jako szczegółowe prob- 
lemy badawcze interesować nas będzie odpowiedź na dwa pytania: 1. Jak Jezus i Jemu współcześni, żyjący w kulturze śródziemnomorskiej owego okresu przeżywali i rozumieli fenomen czasu? 2. Jak wyznawcy Jezusa pojmowali czas w związku z wydarzeniem Jego przyjścia na świat, nauczania połączonego z czynieniem cudów oraz męki, śmierci i zmartwychwstania?

\section{KonCEPCJE CZASU: PERSPEKTYWA \\ FIZYCZNA, FILOZOFICZNA, SOCJOLOGICZNA I ANTROPOLOGICZNA}

Współczesna zachodnia cywilizacja jest zdominowana myśleniem o czasie w kategoriach fizycznych. Człowiek Zachodu, wskutek edukacji oraz wszechobecnego zegarowego i kalendarzowego mierzenia sekund, minut, godzin, dni, tygodni, miesięcy i lat, żyje w paradygmacie Newtonowskiej absolutnej koncepcji czasu, obowiązującej mniej więcej od połowy XIX w. ${ }^{1}$ Według tej koncepcji czas jest wielkością bezwzględną $\mathrm{i}$ upływa tak samo w całym wszechświecie, niezależnie od czynników zewnętrznych. Druga dominująca obecnie fizyczna koncepcja czasu wywodzi się z Einsteinowskiej teorii względności, według której czas jest traktowany jako czwarta współrzędna, obok trzech współrzędnych przestrzennych, z którymi tworzy czterowymiarowe continuum ${ }^{2}$. W tej koncepcji czas nie ma charakteru absolutnego, lecz jest rzeczywistością względną, uzależnioną od układu w przestrzeni materii generującej pole grawitacyjne. Natomiast stałą wartość mają odległości między zdarzeniami w czasoprzestrzeni.

1 Szersze omówienie tych zagadnień znaleźć można np. w monografiach: Zawielski, Czas i jego pomiary; Heller - Pabjan, Elementy filozofii przyrody.

2 Więcej zob. Augustynek, Natura czasu; Heller, „O czasie z różnych punktów widzenia”, 245-248; Heller, Fizyka ruchu i czasoprzestrzeni; Gołosz, „Czas i przestrzeń a świat fizyczny”, 49-61. 
$\mathrm{Na}$ długie wieki przed sformułowaniem koncepcji czasu przez Newtona i Einsteina zagadnienie jego absolutnego bądź względnego charakteru intrygowało filozofów. Według Anaksymandra (ok. 610-546) i Heraklita (ok. 540 - ok. 480) czas jest wieczny (bez początku i końca). Przeciwny do Heraklita pogląd głosił Zenon z Elei (ok. 490 - ok. 430) i jego następcy (filozofia eleatów), którzy zanegowali ruch, twierdząc, że czas jest nieciągły, lecz jest sumą statycznych oderwanych od siebie chwil. Utrzymywali również, że cały wszechświat (w tym także lecąca strzała) jest nieruchomy. Platon (427-347) uważany jest za twórcę cyklicznej koncepcji czasu, czyli tzw. teorii wiecznych powrotów. Jego zdaniem czas nie płynie linearnie, lecz jest zamknięty w kole i cyklicznie powraca. Natomiast wieczność jest niezmienna. W filozofii Platona znajdujemy również koncepcję istnienia aczasowego - w taki właśnie sposób istnieją niezmienne idee. Platońska koncepcja cykliczności czasu dominowała w postrzeganiu tego fenomenu w kulturze śródziemnomorskiej czasów Nowego Testamentu. Zagadnienie czasu było ważnym punktem zainteresowań ucznia Platona Arystotelesa (384-322), który poświęcił mu kilka stron w swojej $F_{i z y c e}$. Według Arystotelesa czas w nierozerwalny sposób łączy się z ruchem. Upływ czasu definiuje on jako odliczanie momentów (wcześniej-teraz-później). Czas dla Stagiryty to przejście od możności do aktu (czyli pochodna ruchu) ${ }^{4}$. Traktuje on czas jako continuum (przeciwnie do eleatów). Arystoteles twierdził jednak, że istnienie czasu jest uwarunkowane ludzkim umysłem, który go mierzy.

Fenomen czasu niezmiennie poprzez wieki intrygował kolejne pokolenia filozofów. Nie miejsce tutaj, by referować wielość proponowanych koncepcji, wspomnimy tylko kilka, które wydają się być istotne dla ukazania szerszego horyzontu podejmowanej w tym artykule problematyki: św. Augu-

Zob. Arystoteles, Fizyka.

4 Heller - Pabjan, Elementy filozofii przyrody, 23-24. 
styna, Kanta, Husserla i Heideggera. Augustyn z Hippony (354-430) był pierwszym chrześcijańskim filozofem i teologiem, który szerzej zajął się tematyką czasu. Poświęcił temu

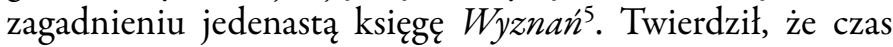
nie jest wieczny, lecz został stworzony przez Boga - Twórcę wszystkiego, a zatem również czasu. Augustyn łączy z jednej strony czas z ruchem dokonującym się w świecie materialnym (czas nigdy nie stoi w miejscu), z drugiej zaś strony twierdzi, że źródłem czasu nie jest ruch niebios, lecz ludzki umysł, który mierzy czas na podstawie doświadczanych przemijających wrażeń. Immanuel Kant (1724-1804) łączy fenomen czasu w sposób konieczny z ludzką zmysłowością ${ }^{6}$ gdyż w jego koncepcji estetyki transcendentalnej czas i przestrzeń są właśnie apriorycznymi formami ludzkiej zmysłowości. To dzięki ludzkiej podmiotowości zmysły dostarczają człowiekowi realnych wrażeń czasoprzestrzennych, które bez tego są idealne, tzn. są niczym. W filozofii Kanta czas przestał być więc traktowany jako byt i stał się domeną zmysłowej aktywności poznawczej człowieka. Z podobnie subiektywistyczną koncepcją czasu co u filozofa z Królewca spotykamy się w systemie fenomenologicznym Edmunda Husserla (1859-1938). Niemiecki filozof utożsamia płynący strumień czasu z samą ludzką świadomością, która ma charakter absolutny i transcendentny zarazem. Husserl twierdzi, że to ludzka świadomość jest źródłem czasu oraz wszelkiego istnienia, któremu nadaje sens. Ostatnią filozoficzną koncepcją czasu, którą chcemy tu w dwóch zdaniach przedstawić jest propozycja Martina Heideggera (1889-1976) ogłoszona w słynnym dziele Sein und Zeit ${ }^{7}$. Heidegger uważa, że czas po prostu „jest” i jest czymś uprzednim w stosunku do bytu. Nie jest on ani własnością przedmiotu, ani podmiotu, gdyż jest „wcześniej” od wszelkiej obiektywności i subiektywności ${ }^{8}$.

\footnotetext{
5 Zob. Augustyn, Wyznania.

6 Szeroko omawia to zagadnienie np. Ustyniak, Cztowiek a czas.

Wydanie polskie zob. Heidegger, Bycie i czas.

8 Zob. więcej: Ustyniak, Cztowiek a czas, 87-130.
} 
Fenomen czasu jest również polem zainteresowań socjologów i antropologów kultury ${ }^{9}$, którzy uważają go za jeden z kluczy do zrozumienia „wielu zagadkowych aspektów ludzkiej myśli i działania"10. Jeżeli jednak miarą wagi zainteresowania danym zagadnieniem jest liczba publikacji, to trzeba powiedzieć, że czas jest w socjologii zagadnieniem peryferyjnym ${ }^{11}$. W socjologii współczesnej patrzy się na czas jako na „zjawisko społeczne, społecznie i kulturowo zmienne, wielostronnie uwarunkowane, nieredukowane do prostych wskaźników ilościowych i do ilościowej tylko charakterystyki"12. W badaniach socjologicznych zjawiska czasu należy brać pod uwagę także wartości, którymi żyje społeczeństwo, konwencje społeczne, gdyż w różnych kontekstach społeczno-kulturowych czas jest różnie przeżywany. Mówi się o przejściu od pojęcia czasu jako miary do pojmowania go jako wartości, czyli w istocie o przejściu od „czasu ekonomicznego do czasu antropologicznego” ${ }^{13}$, od ilościowej do jakościowej koncepcji czasu.

Gdy zaś idzie o spojrzenie na czas przez antropologię kultury, to mimo upływu lat należy powtórzyć tezę Roberta J. Maxwella, który w 1972 r. stwierdził, że pomimo licznych badań terenowych nad koncepcją czasu w różnych kulturach, ciągle brakuje dobrego opracowania teoretycznego obejmującego całość zagadnienia ${ }^{14}$. Choć literatura antropologiczna na temat czasu jest bardzo obfita, to nadal pozostajemy bardziej na poziomie opisu niż kształtowanych dojrzałych koncepcji. Jako dobre podłoże do dalszych szczegółowych badań

9 Syntetycznie zagadnienia te omawia wswej pracy habilitacyjnej: Tarkowska, Czas w spoteczeństwie.

10 Zob. Brandon, History, Time and Deity, V.

11 Zob. Tarkowska, Czas w spoteczeństwie, 9. Za twórcę socjologicznej koncepcji czasu uznaje się francuskiego badacza Émile’a Durkheima (1858-1917). Zob. polski przekład kluczowego tekstu: Durkheim Mauss, $O$ niektórych pierwotnych formach klasyfikacji.

12 Zob. Tarkowska, Czas w spoteczeństwie, 14.

13 Zob. Camargo, „Temps libre”, 299 - cytuję za: Tarkowska, Czas w spoteczeństwie, 14.

14 Zob. Maxwell, „Anthropological Perspectives”, 36-68. 
przedstawionych w niniejszym artykule posłużyć może antropologiczna koncepcja pięciu typów myślenia o czasie zaproponowana przez Edmunda R. Leacha ${ }^{15}$.

Pierwszy typ to czas pierwotny, w którym czas postrzegany jest jako cykl powtarzających się wydarzeń, powracających w określonym następstwie i układających się w ciąg. Cykliczność ta związana jest z porami roku oraz charakterystycznymi dla nich aktywnościami ludzkimi. Cykl życia ludzkiego jest ściśle powiązany z cyklem przyrody. W tym typie czasu nie ma wyraźnego rozróżnienia pomiędzy przeszłością a teraźniejszością, nie liczy się w nim chronologia, nie mierzy się go „zegarowo”. Widać tu dużo zbieżności z omówioną wyżej Platońską koncepcją czasu cyklicznego. Czas historyczny to drugi sposób myślenia o czasie w klasyfikacji Leacha. Uwzględnia się w nim następstwo i porządek zdarzeń oraz chronologię. Czas historyczny jest nieciągły, liczy się w nim trwanie mierzone nieporównywalnymi ze sobą odcinkami. Pomiędzy kolejnymi zdarzeniami historycznymi pojawiają się okresy czasowo puste. W tym typie czasu myśli się w kategoriach następstwa sekwencyjnego, a nie cyklicznego. Trzeci typ to czas magiczny charakterystyczny dla myślenia religijnego i magicznego. Jego istotną cechą jest możliwość oddziaływania na zdarzenia lub poddawanie się zdarzeniom poprzez podejmowane działania, np. praktyki rytualne. Rzeczywistość zdarzeniowa opisywana w kategoriach czasu magicznego jest widziana jako kontrolowana, przekształcana i podatna na zmiany. Kolejny typ to czas naukowy, rozumiany jako czyste trwanie bez jakichkolwiek odniesien. Taki czas jest postrzegany jako wielkość mierzalna w precyzyjnych odcinkach zgodnie z przyjętą skalą. Jest to czas ciągły. Koncepcja ta posiada sporo zbieżności z przedstawionym powyżej Newtonowskim absolutnym rozumieniem czasu. Ostatni typ to czas polityczny. Jest to czas manipulowany, kontrolowany, wyrażany przez przyjęte w społeczeństwach kalendarze prze-

15 Zob. Leach, „Primitive Time-Reckoning”, 110-127. 
łomowych ruchów rewolucyjnych. Myślenie o czasie jest tu podporządkowane celom władców i związane z ich działaniami. W przedstawionym tu skrótowo modelu E.R. Leacha znajduje odbicie zarówno filozoficzne, jak i socjologiczno-antropologiczne postrzeganie czasu.

\section{Propozycja ŚWieżego SPOJRZenia NA ZAGADNIENIE "JEZUS A CZAS”}

Warunkiem w miarę obiektywnego wyjaśnienia tematyki "Jezus a czas" jest ustalenie tego, jak pojmowali czas mieszkańcy starożytnego świata śródziemnomorskiego w okresie życia Jezusa i powstawania ksiąg Nowego Testamentu. Jak słusznie zauważa Bruce J. Malina „Rozumienie percepcji czasu przez autorów biblijnych jest fundamentalne dla zrozumienia ich tekstów" ${ }^{\prime 16}$. Trzeba zauważyć, że egzegeci zasadniczo stronią od podejmowania badań tematyki czasu w Biblii. Hasło „Czas” jest niemal nieobecne w słownikach i leksykonach biblijnych, a jeżeli się tam pojawia, to jego autorzy są zaprzątnięci przede wszystkim kwestiami filologicznymi, na podstawie których formułują wnioski teologiczne (zwłaszcza rozróżnienie pomiędzy chronos a kairos). Do dzisiaj jedyną znaną nam naukową monografią poświęconą stricte tematyce "Jezus a czas" jest praca Oscara Cullmanna opublikowana po raz pierwszy w szwajcarskim Zurichu w 1946 r. w niemieckojęzycznym oryginale Christus und die Zeit ${ }^{17}$. Około czterdziestu lat później, w 1989 r., konstruktywną polemikę z hipotezą O. Cullmanna podjął amerykański biblista z nurtu social

16 Zob. Malina, „Christ and Time”, 2.

17 Korzystamy tutaj z angielskiego przekładu tego dzieła: Cullmann, Christ and Time. 
science ${ }^{18}$ Bruce J. Malina. Prace tych dwóch badaczy będą dla nas podstawowymi punktami odniesienia w dalszym wyjaśnianiu problematyki "Jezus a czas”.

Oscar Cullmann podchodzi do zagadnienia „Chrystus a/i czas" z dobrym warsztatem egzegety nurtu historyczno-krytycznego. Najpierw stawia problem badawczy w perspektywie historycznej i teologicznej oraz formułuje tezę, którą będzie starał się uzasadnić w monografii. Twierdzi on mianowicie, że istniała zasadnicza różnica w podejściu do czasu w tradycji biblijnej i w kulturze hellenistycznej. W Biblii traktowanej jako Stary i Nowy Testament historia zbawienia jest ukazywana w sposób linearny, a zbawcze dzieło Chrystusa jest centralnym punktem historii świata. Natomiast w kulturze hellenistycznej obowiązywała cykliczna koncepcja czasu scharakteryzowana powyżej jako platońska ${ }^{19}$. Na podstawie owej dychotomii Cullmann rozwija myśl o wydarzeniu Chrystusa jako centralnym punkcie historii odkupienia człowieka. Monografia Cullmanna została wkrótce przetłumaczona na języki francuski, angielski i japoński, a jego teza znalazła wielu zwolenników, ale także licznych przeciwników (zwłaszcza w Niemczech) ${ }^{20}$. Krytyka nie dotyczyła jednak fundamentalnego rozróżnienia pomiędzy biblijną-linearną koncepcją czasu a hellenistyczną-cykliczną, lecz kwestii teologicznych i filologicznych, gdy idzie o semantykę biblijnego słownictwa określającego czas ${ }^{21}$.

Uznając niezbywalną wysoką jakość analiz dokonanych przez Cullmanna, trzeba stwierdzić, że mamy tu do czynienia

$18 \mathrm{Na}$ potrzeby niniejszego artykułu social science w ujęciu B.J. Maliny utożsamiamy z podejściem antropologicznokulturowym. W istocie jednak podejście antropologicznokulturowe ma o wiele szersze spektrum. Zagadnienie to omawiamy szeroko w: Kręcidło, Honor i wstyd winterpretacji Ewangelii, 3.

19 Kręcidło, Honor i wstyd w interpretacji Ewangelii, 51-60.

20 Autor omawia te rzeczy we wstępie do trzeciego wydania, s. XVII-XXXI.

21 Tutaj zwłaszcza krytyczna ocena Jamesa Barra zawarta w przełomowej pozycji The Semantics of Biblical Language oraz w Biblical Words for Time. 
bardziej z eisegezą niż z egzegezą. Jego monografia stanowi przykład używania tekstów biblijnych do udowadniania aktualnych dwudziestowiecznych koncepcji teologicznych niż próbę rekonstrukcji teologicznych poglądów autorów Nowego Testamentu. B.J. Malina wykazuje w swoim artykule, że zastosowane przez Cullmanna fundamentalne rozróżnienie pomiędzy judaistyczno-chrześcijańską linearną koncepcją czasu a hellenistyczną cykliczną jest błędnym założeniem ${ }^{22}$. Również w naszej opinii wyizolowywanie kultury biblijnej z kultury świata śródziemnomorskiego wydaje się być metodologicznym nadużyciem. Czas to domena ludzkiego doświadczenia typowego dla jednostek wyrosłych w społeczeństwie o danej kulturze $^{23}$. Zgodnie z dzisiejszym stanem badań antropologicznokulturowych starożytny świat śródziemnomorski stanowił koherentne milieu kulturowe ${ }^{24}$, a skoro tak, to również sposób przeżywania i rozumienia czasu powinien być wspólny, niezależnie od przynależności narodowej czy religijnej.

B.J. Malina, używając narzędzi typowych dla social scien$c e$, porównuje podejście do czasu ludzi wychowanych we współczesnej zachodniej cywilizacji z tym, jak postrzegali siebie w czasie ludzie świata śródziemnomorskiego w okresie Nowego Testamentu. Dochodzi do wniosku, że mentalność współczesnego człowieka Zachodu jest zorientowana na przyszłość (ang. future oriented), natomiast ludzie w kulturze śródziemnomorskiej byli zorientowani na przeżywanie teraźniejszości, a ich czasowy horyzont ograniczał się zasadniczo do perspektywy ich własnego życia ${ }^{25}$. Amerykański biblista weryfikuje tę tezę uciekając się do sprawdzonego antropologicznego modelu preferencji wyboru wartości zaproponowa-

22 Wcześniej takie same zarzuty kierowali wkierunku monografii Cullmanna np. Momigliano, Time in Ancient Historiography; Boman, Hebrew Thought Compared with the Greek; Gabba, „True History and False History", 50-62.

23 Zob. argumentację: Malina, „Christ and Time”, 2-4.

24 Zob. Kręcidło, Honor i wstyd w interpretacji Ewangelii, zwłaszcza 29-37.

25 Zob. Malina, „Christ and Time”, zwłaszcza 4-7. 
nego przez Florence R. Kluckhohn i Freda L. Strodbecka ${ }^{26}$. Ów wszechstronny model, znajdujący zastosowanie w różnych dziedzinach nauki i praktyczne wykorzystanie w życiu, został zaaplikowany przez Malinę, który sformułował pytanie odnośnie do postrzegania czasu przez ludzi Nowego Testamentu na podstawie analizy jego treści: „Czy ludzie, gdy napotykają na poważne problemy, instynktownie zwracają się do przeszłości, teraźniejszości czy też przyszłości, by znaleźć ich rozwiązanie?"27. Pytaniu temu towarzyszą inne - pomocnicze - które pozwalają lepiej ugruntować przekonanie o tym, że orientacja czasowa ludzi okresu Nowego Testamentu była ukierunkowana na teraźniejszośćc ${ }^{28}$. Nie oznacza to wszakże, że orientacja na teraźniejszość eliminuje dwie pozostałe. W różnych cywilizacjach dominuje zawsze jedna z trzech perspektyw czasowych, nie wykluczając jednak dwóch pozostałych ${ }^{29}$.

Zorientowanie na teraźniejszość ludzi okresu Nowego Testamentu nie wynikało z religijno-biblijnych przesłanek wyznawców Chrystusa, lecz było wspólne dla ludzi kultury świata śródziemnomorskiego w tym okresie. Idąc krok dalej niż spojrzenie antropologicznokulturowe, które przedstawił B.J. Malina, można pokusić się o pewną syntezę i wspólną płaszczyznę z ujęciami przedstawionymi powyżej w naszym artykule. Otóż zorientowane na teraźniejszość myślenie o czasie, charakterystyczne dla ludzi świata śródziemnomorskiego czasów Nowego Testamentu ma cechy wspólne z cykliczną platońską koncepcją czasu oraz z czasem pierwotnym w referowanym powyżej modelu E.R. Leacha. Wspólną cechą doświadczenia

26 Zob. Kluckhohn -Strodbeck i in., Variations in Value Orientations.

27 Zob. Malina, „Christ and Time”, 5.

28 Malina, „Christ and Time”, 5.

29 Dla Maliny podstawową orientacją czasową ludzi okresu NT jest teraźniejszość, na drugim miejscu przeszłość, a na końcu dopiero myślenie o przyszłości. Jest to myślenie typowe dla środowisk wiejskich. Jedynym wyjątkiem były rzymskie elity, gdzie przeważała orientacja czasowa na przeszłość (potem teraźniejszość i na końcu przyszłość - długoterminowe planowanie było Rzymianom obce). Zob. Malina, „Christ and Time”, 5-6. 
czasu we wszystkich tych ujęciach jest zorientowanie na cykliczność przeżywaną w teraźniejszości. Oczywiście jest to ujęcie bardzo uproszczone, ale jego zaletą jest to, że może stanowić dobry punkt wyjścia do dalszych uszczegółowień.

W przypadku Nowego Testamentu sprawa wydaje się nam jednak bardziej skomplikowana - wykraczamy tu mocno poza antropologicznokulturowy model B.J. Maliny i koncepcyjnie ukierunkowujemy się na teologiczne ujęcie O. Cullmanna. Uważamy bowiem, że kulturowa mentalność pierwszych chrześcijan, choć zorientowana na teraźniejszość, została w zasadniczy sposób przeorientowana na eschatologiczną przyszłość wskutek wydarzenia męki, śmierci, zmartwychwstania i wniebowstąpienia Jezusa Chrystusa oraz oczekiwania Jego paruzji, która może wydarzyć się w każdym pokoleniu „Lecz o dniu owym i godzinie nikt nie wie, nawet aniołowie w niebie, tylko sam Ojciec" (Łk 24,36). Z punktu widzenia bohaterów ksiąg Nowego Testamentu i ich autorów nie bez znaczenia jest również czasowe zorientowanie na przeszłość, o czym świadczy zwłaszcza częste odwoływanie się do wydarzeń z historii zbawienia Starego Testamentu oraz używanie argumentów skrypturystycznych (Pisma i prorockie zapowiedzi wypełniają się). W dalszej części artykułu krótko ukażemy na przykładzie wybranych tekstów Nowego Testamentu, jak funkcjonują w nim owe trzy perspektywy czasowe.

Nie wchodząc już głębiej w rozważania natury teoretyczno-metodologicznej spróbujemy pokazać, inspirując się zwłaszcza antropologicznokulturowym ujęciem B.J. Maliny, jakie znaczenie dla właściwego odczytania teologii Nowego Testamentu ma interpretowanie tych tekstów w perspektywie podejścia do czasu właściwej dla Jezusa i Jego naśladowców w pierwszych wiekach chrześcijaństwa. Wydaje się to bardzo istotnie, gdyż współczesny czytelnik Nowego Testamentu wychowany w zorientowanej na przyszłość mentalności może interpretować słowa Jezusa i biblijne narracje niezgodnie z ich pierwotnym sensem. Na przykład, gdy współczesny odbiorca Ewangelii czyta Jezusowe zapowiedzi powtórnego przyjścia 
Syna Człowieczego, to interpretuje je jako zapowiedź paruzji Chrystusa w czasach ostatecznych. Natomiast dla zorientowanych mentalnościowo na teraźniejszość ludzi czasów Nowego Testamentu wypowiedzi takie nie odnosiły się na pierwszym miejscu do odległej przyszłości, lecz do przyszłości sięgającej nie dalej jak kres ich życia. Na taką interpretację wskazują występujące w kontekście Jezusowych wypowiedzi o Synu Człowieczym takie Jego wyjaśnienia, jak: „Zaprawdę, powiadam wam: Niektórzy z tych, co tu stoją, nie zaznają śmierci, aż ujrzą królestwo Boże przychodzące w mocy" (Mk 9,1 i par.); „Zaprawdę, powiadam wam: Nie przeminie to pokolenie, aż się to wszystko stanie" (Mk 13,30 i par.).

$\mathrm{Na}$ teraźniejszą orientację słuchaczy Jezusa wyraźnie wskazują również inne wypowiedzi. Orientacja czasowa na teraźniejszość daje się wywnioskować np. ze słów Modlitwy Pańskiej: „Chleba naszego powszedniego daj nam dzisiaj” (Mt, 6,11; por. Łk 11,3). Nieco dalej, kontynuując Kazanie na Górze, w kontekście pouczeń, by nie troszczyć się zbytnio o sprawy doczesne, Jezus mówi: „Nie troszczcie się więc zbytnio o jutro, bo jutrzejszy dzień sam o siebie troszczyć się będzie. Dosyć ma dzień swojej biedy" (Mt 6,34). Dobrym przykładem zorientowania na teraźniejszą perspektywę czasową mogą być także mowy pożegnalne Jezusa z J 13-17. Zaczynają się one stwierdzeniem narratora, że nadeszła godzina przejścia Jezusa z tego świata do Ojca $(13,1)$, a zatem rychłego wejścia $\mathrm{w}$ futuryczną z punktu widzenia uczniów perspektywę czasową. Całe mowy pożegnalne są jednak zorientowane na trwanie uczniów w Jezusie w teraźniejszości (zwłaszcza rozdział 15) pod opieką Ducha Parakleta, którego Jezus obiecuje posłać im, gdy powróci do Ojca ${ }^{30}$. W Dziejach Apostolskich zmartwychwstały Jezus, tuż przed swoim wniebowstąpieniem, odpowiada na ich pytanie „Panie, czy w tym czasie przywrócisz królestwo Izraela?” w następujących słowach: „Nie wasza to rzecz znać czasy i chwile, które Ojciec

30 Zob. Kręcidło, The Spirit Paraclete, zwłaszcza 89-108. 
ustalił swą władzą, ale gdy Duch Święty zstąpi na was, otrzymacie Jego moc i będziecie moimi świadkami w Jerozolimie i w całej Judei, i w Samarii, i aż po krańce ziemi" $(1,6-8)$. Jest to wyraźne zalecenie, by uczniowie byli zorientowani na teraźniejszość, w której mają być świadkami Chrystusa.

Uczniowie Jezusa i autorzy ksiąg Nowego Testamentu przeżywają swoje istnienie również $\mathrm{w}$ orientacji czasowej na przeszłość. Jest to charakterystyczne zwłaszcza dla uczniów Jezusa w pierwszym pokoleniu - palestyńskich Żydów wyrosłych w wierze Starego Testamentu. Perspektywa ta wydaje się być natomiast mniej ważna dla wiernych nawróconych z pogaństwa, żyjących w licznych wspólnotach uczniów Jezusa w całym basenie Morza Sródziemnego, chociaż należy wziąć również pod uwagę, że ci, którzy głosili im Ewangelię i pisali do nich listy byli wychowani w starotestamentowej mentalnościowo-religijnej matrycy. Orientacja czasowa na przeszłość u uczniów Jezusa pochodzenia żydowskiego wynikała z natury wiary ludu Starego Testament, która zasadzała się na historiozbawczej obecności Boga Stwórcy i Wyzwoliciela w losach wybranego przez siebie narodu. Wiara starotestamentowa to wiara oparta na pamięci zbawczego działania Boga w przeszłości, które aktualizuje się w teraźniejszości każdego pokolenia. Teraźniejszość ta była przeżywana jako wypełnienie Bożych obietnic, objawionych w Torze, w Prorokach i w Pismach. Można zaryzykować twierdzenie, że wiara starotestamentowa nie istnieje w teraźniejszości, jeżeli nie jest przeżywana jako aktualizacja przeszłości. Nie wchodząc głębiej w ten temat, należy przyjąć, że wiara Żydów Starego Testamentu sprawiała, że typowa dla kultury świata śródziemnomorskiego orientacja czasowa na teraźniejszość, była przez nich przeżywana nieco inaczej niż przez ogół obywateli cesarstwa - teraźniejszość to aktualizacja przeszłości, a zatem orientacja na przeszłość ma również istotne znaczenie.

Z taką właśnie mentalnością spotykamy się u uczniów Jezusa i autorów ksiąg nowotestamentowych. Istotnym elementem przyjętej przez nich nowej wiary była orientacja na przeszłość. 
Wcielenie i zbawcze dzieło Chrystusa jest interpretowane przez nich jako wypełnienie starotestamentowych mesjańskich zapowiedzi. Autorzy, opowiadając o Jego słowach i czynach, interpretują je w świetle starotestamentowych postaci $\mathrm{i}$ istotnych dla wiary Starego Testamentu toposów. Dobrym przykładem orientacji czasowej na przeszłość, która aktualizuje się w teraźniejszości jest hymn Magnificat w Łk 1,46-56 czy też Zachariaszowy Benedictus w Łk 1,67-79. Inną doskonałą ilustracją może być np. mowa Piotra do Żydów zgromadzonych w Jerozolimie w dniu Pięćdziesiątnicy (Dz 2,14-36).

Przejdźmy na koniec do zagadnienia, które stanowi istotę argumentacji B.J. Maliny w artykule „Christ and Time”. Autor ten twierdzi mianowicie, że na kartach Ewangelii oraz niemal wszystkich pozostałych ksiąg Nowego Testamentu nie ma śladów orientacji czasowej na przyszłość, która sięgałaby poza granice życia pokolenia adresatów słów Jezusa. Twierdzi on, że ślady eschatologii futurycznej przekraczającej granice tamtego pokolenia pojawiają się dopiero w najpóźniejszych księgach Nowego Testamentu ${ }^{31}$. W naszej opinii na zagadnienie to należy patrzeć nieco inaczej. Otóż wydarzenie męki, śmierci i zmartwychwstania Chrystusa zmienia radykalnie perspektywę postrzegania czasu przez uczniów Jezusa i wyznacza jednocześnie model przeżywania czasu przez chrześcijan wszystkich pokoleń aż do dnia paruzji Chrystusa. Dla ludzi Nowego Testamentu przeszłość, teraźniejszość i przyszłość ogniskują się w wydarzeniu Chrystusa i w Nim nabierają sensu. W Nim rozpoczyna się eschatologiczna przyszłość, która w każdym kolejnym pokoleniu w historii świata przeżywana jest jako „teraz” zbawienia. Takie myślenie pojawia się nie tylko w najpóźniejszych czasowo księgach Nowego Testamentu, lecz przenika je wszystkie - począwszy od najstarszych listów Pawła (kerygmat o zbawieniu w Chrystusie), przez Ewangelie, do pism zredagowanych najpóźniej. W kategoriach antropologii kulturowej jest to orientacja na teraźniejszość ściśle po-

31 Zob. Malina, „Christ and Time”, 6-30. 
łączona z orientacją futuryczną - i jak pokazaliśmy powyżej - z historiozbawczym doświadczeniem przeszłości. Takie spojrzenie odsuwa na dalszy plan myślenie eschatologiczne w kategoriach kosmicznej katastrofy inicjującej paruzję Chrystusa na końcu czasów, nie wykluczając jej jednak.

\section{Podsumowanie I WNioski}

W artykule przedstawione zostało w szerokim zakresie zagadnienia czasu. Najpierw krótko zaprezentowaliśmy fizyczne koncepcje czasu, zwłaszcza Newtonowską i Einsteinowską. Kolejnym krokiem była syntetyczna charakterystyka najważniejszych koncepcji filozoficznych odnośnie do czasu - od starożytności po współczesność. Następnie nieco miejsca poświęciliśmy socjologicznemu i antropologicznokulturowemu spojrzeniu na zjawisko czasu. Te syntetyczne prezentacje bardzo złożonych zagadnień miały za zadanie przygotować tło do spojrzenia na zjawisko czasu z perspektywy ludzi czasów Nowego Testamentu. Po zrelacjonowaniu ujęć O. Cullmanna (linearna koncepcja czasu) i B.J. Maliny (zorientowanie na teraźniejszość) zaproponowaliśmy własne rozwiązanie, według którego uczniowie Jezusa rozumieli czas w bardziej złożony sposób. Po pierwsze, jako ludzie świata śródziemnomorskiego tamtego okresu przeżywali czas cyklicznie z orientacją na teraźniejszość (czas prymitywny w modelu Leacha). Po drugie, jako nawróceni Żydzi wychowani na wierze Starego Testamentu przeżywali teraźniejszość jako historiozbawczą aktualizację przeszłości, która wypełniła się w wydarzeniu Jezusa Chrystusa. Po trzecie, wydarzenie męki śmierci i zmartwychwstania wprowadza radykalnie nową perspektywę przeżywania czasu przez chrześcijan pierwszego pokolenia oraz wszystkich następnych generacji aż do skończenia świata. Zmartwychwstanie Chrystusa ogniskuje w sobie przeszłość, teraźniejszość i przyszłość, i nadaje im nową jakość, każąc przeżywać życie jako „teraz” zbawienia. 
Arystoteles, Fizyka (przekład, wstęp i przypisy K. Leśniak)

(Warszawa: Państwowe Wydawnictwo Naukowe 1968).

Augustyn, Wyznania (tł. Z. Kubiak) (Kraków: Wydawnictwo Znak $\left.{ }^{4} 2007\right)$.

Augustynek Z., Natura czasu (Warszawa: Państwowe Wydawnictwo Naukowe 1975).

Barr J., Biblical Words for Time (Napierville: A.R. Allenson 1962).

Barr J., The Semantics of Biblical Language (London: Oxford University Press 1961).

Boman T., Hebrew Thought Compared with the Greek (London: SCM Press 1960).

Brandon S.G.F., History, Time and Deity. A Historical and Comparative Study of the Concept of Time in Religious Thought and Practice (Manchester: Manchester University Press 1965).

Durkheim É. - Mauss M., „O niektórych pierwotnych formach klasyfikacji. Przyczynek do badań nad wyobrażeniami zbiorowymi", Mauss M., Socjologia i antropologia (Warszawa: Państwowe Wydawnictwo Naukowe 1973).

Camargo L.O., „Temps libre - temps inoccupé dans les sociétés en voie de développement - le cas du Brésil", Loisir et Société 2/5 (1982) 297-302.

Cullmann O., Christ and Time. The Primitive Christian Conception of Time and History (transl. F.V. Filson) (London: SCM Press [revised edition with a new introductory chapter] 1962).

Gabba E., „True History and False History in Classical Antiquity", The Journal of Roman Studies 71 (1981) 50-62.

Gołosz J., „Czas i przestrzeń a świat fizyczny”, Zagadnienia filozoficzne w nauce 17 (1995) 49-61.

Heidegger M., Bycie i czas (Warszawa: Wydawnictwo Naukowe PWN 2017). 
Heller M., Fizyka ruchu i czasoprzestrzeni (Warszawa: Wydawnictwo Naukowe PWN 1993).

Heller M., „O czasie z różnych punktów widzenia”, Znak 2/308 (1980) 245-248.

Heller M. - Pabjan T., Elementy filozofii przyrody (Kraków: Copernicus Center Press 2014).

Kluckhohn F.R. - Strodbeck F.L. i in., Variations in Value Orientations (Evanston: Row, Peterson 1961).

Kręcidło J., Honor i wstyd w interpretacji Ewangelii. Szkice z egzegezy antropologicznokulturowej (Warszawa: Verbinum 2013).

Kręcidło J., The Spirit Paraclete and Jesus in the Gospel of John (Kraków: Wydawnictwo La Salette Księży Misjonarzy Saletynów 2008).

Leach E.R., „Primitive Time-Reckoning”, History of Technology (red. C. Singer - E.J. Holmyard - A.R. Hall) (Oxford: Clarendon Press 1956) I, 110-127.

Malina B.J., „Christ and Time: Swiss or Mediterranean”, Catholic Biblical Quarterly 51 (1989) 1-30.

Maxwell R.J., „Anthropological Perspectives”, The Future of Time. Man's TemporalEnvironment $(\mathrm{H}$. Yaker $-\mathrm{H}$. Osmond

- F. Cheek) (Garden City, N.Y.: Doubleday 1972) 36-68.

Momigliano A., Time in Ancient Historiography (Middletown: Wesleyan University Press 1966).

Tarkowska E., Czas w spoteczeństwie. Problemy, tradycje, kierunki badań (Wrocław: Zakład Narodowy im. Ossolińskich; Wydawnictwo Polskiej Akademii Nauk 1987).

Ustyniak I., Cztowiek a czas: Kant, Husserl, Heidegger (praca doktorska, Wydział Filozoficzno-Historyczny Uniwersytetu Łódzkiego; Łódź 2014).

Zawielski S.F., Czas i jego pomiary (tł. M. Kalisz) (Warszawa: Państwowe Wydawnictwo Naukowe 1981). 
Ks. JANUSZ KRĘCID£O, saletyn, profesor zwyczajny nauk teologicznych, kierownik studiów doktoranckich, kierownik Katedry Egzegezy Nowego Testamentu oraz dyrektor Instytutu Nauk Biblijnych na Wydziale Teologicznym Uniwersytetu Kardynała Stefana Wyszyńskiego w Warszawie. 
